\title{
Variation in the Chemistry of Aerosols in two Different Winter Seasons at Pune and Sinhagad, India
}

\section{Pramod Digambar Safai*, Pasumarti Surya Prakasa Rao, Gafur Abulal Momin, Kaushar Ali, Dilip Motiram Chate, Puppala Siva Praveen and Panuganti China Sattilingam Devara.}

\author{
Indian Institute of Tropical Meteorology, Pune - 411008
}

\begin{abstract}
Samples of Total Suspended Particulates (TSP) were collected at Pashan, Pune (semi-urban) and Sinhagad (rural) locations in India, during the winter season of 2003/4, using a high volume air sampler and were analyzed for major water-soluble chemical components using Ion Chromatograph and Atomic Absorption Spectrophotometer. Results of the study were compared with those reported for the same locations in winter season, about two decades back. It was observed that TSP and all of its chemical components showed marked increase in concentrations after the period of two decades at both Pune and Sinhagad. Especially, for $\mathrm{NH}_{4}{ }^{+}, \mathrm{SO}_{4}{ }^{2-}, \mathrm{NO}_{3}{ }^{-}$and $\mathrm{Ca}^{2+}$, the concentrations increased by about 9, 7,7 and 4 times at Pune and about 23,10,10 and 6 times at Sinhagad, respectively. This feature shows the significant impact of anthropogenic activities at both the locations. $\mathrm{SO}_{4}{ }^{2-}$ is still the main acidifying component of aerosols and $\mathrm{NH}_{4}{ }^{+}$dominates over $\mathrm{Ca}^{2+}$ in the neutralization of acidity in 2003/4 whereas earlier two decades back, $\mathrm{Ca}^{2+}$ was the major neutralizer.
\end{abstract}

Keywords: TSP, chemical composition, acidity, neutralization potential.

\section{Introduction}

Aerosols have been a vital link between the source-transport-deposition of various pollutants in the atmosphere. Chemical nature of aerosols is one of the important factors in assessing the impact of aerosols after their deposition on terrestrial as well as aquatic surfaces. Studies on the composition of aerosols, reported from the Indian region are mainly from urban/semi-urban locations (Khemani et al 1982; Kulshrestha et al 1998, Momin et al, 1999; Rao et al, 2001; Ali et al, 2002), whereas, those from the rural or remote regions are very few (Khemani et al, 1985; Mahadevan et al, 1989; Safai et al, 1993 and 2004a). Also the changes in the aerosol composition, after a considerable period of time

\footnotetext{
${ }^{*}$ Corresponding author. Tel: +91-020-25893600; Fax: +91-020-25893825.

E-mail address: pdsafai@tropmet.res.in
} 
are not sufficiently documented mainly due to the scarcity of past data. Studies were carried out on Total Suspended Particulates (TSP) at Pashan, Pune and at Sinhagad during the winter season of 2003/4. Results obtained from this study have been compared with those reported for winter season at the same locations, more than twenty years back i.e. in 1978 for Pune and in 1982 for Sinhagad (Khemani, 1989). The main objective of the present study is to investigate the variation in concentrations of major acidifying $\left(\mathrm{SO}_{4}{ }^{2-}\right.$ and $\left.\mathrm{NO}_{3}{ }^{-}\right)$and alkaline $\left(\mathrm{Ca}^{2+}\right.$ and $\left.\mathrm{NH}_{4}{ }^{+}\right)$constituents of aerosols and their effect on the acidification/neutralization potential of aerosols. The results presented here are confined to the winter season only and are not representative of the annual cycle. Due to the frequent inversion conditions and low ventilation coefficients prevailing over this region the in winter (Devara et al, 2001), the pollution potential is rather more in this season and and it is of interest to study the chemistry of aerosols in view of the assessment of atmospheric composition over this region particularly in winter.

\section{Sampling Locations and Methodology}

TSP samples were collected at Pune $\left(18^{0} 32^{\prime} \mathrm{N}, 73^{0} 51^{\prime} \mathrm{E}, 559 \mathrm{~m}\right.$ asl), during 29 Dec. 2003 to 9 Jan. 2004 and those at Sinhagad $\left(18^{0} 21^{\prime} \mathrm{N}, 73^{\circ} 45^{\prime} \mathrm{E}, 1400 \mathrm{~m}\right.$ asl $)$ were collected during $27 \mathrm{Jan}$. to 1 Feb. 2004. Pune is about $100 \mathrm{~km}$ inland on west coast of India, on the leeward side of Western Ghats. Sampling was carried out on the terrace of the building at about $10 \mathrm{~m}$ above the surface, at the Indian Institute of Tropical Meteorology, Pashan, Pune. Pashan is a semi-urban site, located about $10 \mathrm{kms}$ from the center of Pune city. The site is surrounded on all sides by hillocks of variable heights (up to $200 \mathrm{~m}$ ), forming a valley like appearance. Brick kilns are situated at a distance of about $1 \mathrm{~km}$ to the west of observational site. The major urban activity goes on to the east of the observational site. Pune receives marine as well as continental airmasses during different seasons. During June to September, southwesterly and westerly winds, rich with marine airmasses from the Indian Ocean and Arabian Sea, prevail over this region. Whereas, from December through February, during the winter season, easterlies coming over from the land and rich with the continental airmasses, dominate over this region. The industrial sources have been located to the north, north-west of the city. Also, there are more than 13,00,000 vehicles of which, about 10,00,000 are two-wheelers. The population of the city is nearly 25,00,000. Figure 1 shows the growth in population as well as industries in Pune district. Though this figure depicts values for the whole district, it would certainly give some idea about the rapid increase from 1960's up to 1990's in both industries as well as population in this region. However, after 1990, these growth rates have been stabilised (District Social and Economic Summary, Pune District, 1999-2000). The construction activity is still on the rise in all the surroundings of the city especially around the present site. 


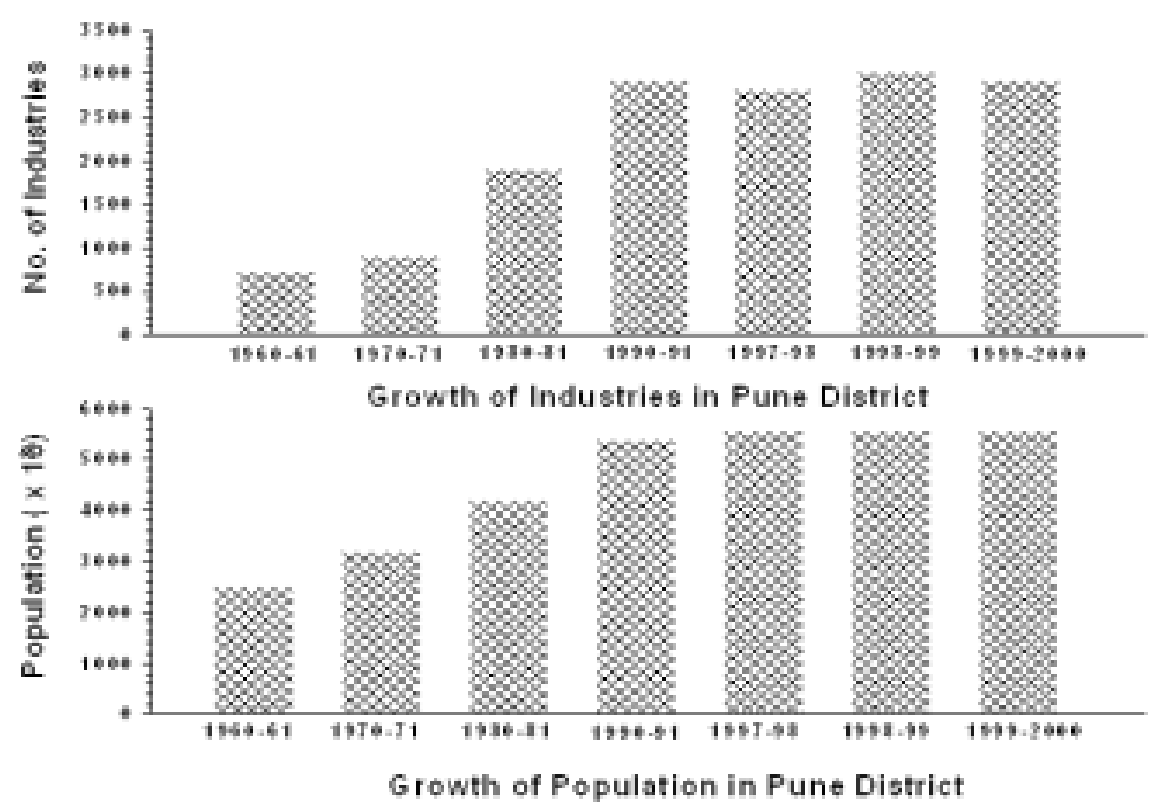

Figure 1. The growth in population as well as industries in Pune district during 1960-2000.

Sinhagad is a historical fort situated on the hill at a mountain top in the Western Ghat region. It is located about $40 \mathrm{~km}$ by road, to the southwest of Pune. The top of the hill is flat terrain with an area of about $0.5 \mathrm{sq}$. $\mathrm{km}$ and is surrounded by other mountain peaks of comparable heights. The area is covered with vegetation during monsoon season (June to September). Local inhabitants on the fort are very few. The only noticeable local source of pollution is wood burning, mainly for cooking. A few vehicles, mainly cars, jeeps and two-wheelers, enter the mountain but they have to stop at the entrance of the fort only. The sampling of TSP was carried out in the complex of a Micro wave tower building owned by Bharat Sanchar Nigam Limited (BSNL), Government of India. It is a protected site and tresspassers or tourists are not allowed to enter. Thus, it can be considered to be a rural, least polluted site.

A high volume sampler (Anderson Inc., USA, Model 2200) was used for the collection of TSP samples on Whatman No. 41 filter papers of size 8 inch by 10 inch. The average flow rate of sampling was about $1.2 \mathrm{~m}^{3} / \mathrm{min}$ and the sampling duration for each sample was about 6 hours. The filter papers were equilibrated for humidity before and after the weighing. After the sampling, the filter papers were extracted for water soluble chemical components $\left(\mathrm{Cl}^{-}, \mathrm{SO}_{4}{ }^{2-}, \mathrm{NO}_{3}{ }^{-}, \mathrm{NH}_{4}{ }^{+}, \mathrm{Na}^{+}, \mathrm{K}^{+}\right.$, $\mathrm{Ca}^{2+}$ and $\left.\mathrm{Mg}^{2+}\right)$. Chemical analysis of anions $\left(\mathrm{Cl}^{-}, \mathrm{SO}_{4}{ }^{2-}\right.$ and $\left.\mathrm{NO}_{3}{ }^{-}\right)$was carried out with the help of Ion Chromatograph (Dionex DX-100) using analytical columns Ion Pac-AS4A- SC 4mm, anion micro membrane suppressor ASRS -1, 1.8mM Sodium Carbonate/1.7mM Bicarbonate as eluent and triple distilled water as regenerant. Atomic Absorption Spectrophotometer (Perkin Elmer 373) was used for the analysis of cations $\left(\mathrm{Na}^{+}, \mathrm{K}^{+}, \mathrm{Ca}^{2+}\right.$ and $\left.\mathrm{Mg}^{2+}\right)$ and $\mathrm{NH}_{4}^{+}$was analyzed using spectrophotometric method (Weatherburn, 1967). The detection limit for ion chromatographic analysis was about $0.01 \mathrm{ppm}$ whereas, that for the atomic absorption spectrophotometric analysis varied from 0.002 to $0.02 \mathrm{ppm}$. Field Blanks were taken and analyzed, using procedures similar to 
those adopted for samples and necessary correction factors were taken into consideration while computation of ionic concentrations. Detailed procedures of sampling and analysis techniques have been mentioned elsewhere (Safai, 1999).

The earlier observational site at Sinhagad (during 1982) was about 200 meters away from the present site indicating negligible spatial difference however, the surroundings have changed considerably and the human activities (especially tourist related) have increased significantly in the last 20 years. At Pune, the observational site was near city center (about $3 \mathrm{kms}$ ) in 1978 whereas the present site is seven $\mathrm{km}$ further away from city center. But as far as the human activities (like vehicular and constructional) are concerned, situation at the site in 1978 more or less resembles the present site as the city has expanded vastly in last two decades. Regarding sampling and analysis part, filter media used in the earlier observations was Whatman 41 only, but with circular shape of 10 um dia and average flow rate was about $0.7 \mathrm{~m}^{3} / \mathrm{min}$. The duration of each sample was about $3 \mathrm{hrs}$. in 1978-82 period. A handy high volume sampler (GMW Inc., USA, Model 2000) was used for TSP collection. Analysis of cations $\left(\mathrm{NH}_{4}^{+}, \mathrm{Na}^{+}, \mathrm{K}^{+}, \mathrm{Ca}^{2+}\right.$ and $\left.\mathrm{Mg}^{2+}\right)$ was carried out using same techniques as those in present study. However, anions $\left(\mathrm{Cl}^{-}, \mathrm{SO}_{4}{ }^{2-}\right.$ and $\left.\mathrm{NO}_{3}{ }^{-}\right)$were analysed by spectrophotometric method for which detection limit varied from 0.01 to $0.1 \mathrm{ppm}$ (Safai, 1999). The compatibility of this method with the ion chromatographic technique, was assessed and found to be statistically satisfactory.

\section{Results and Discussions}

\subsection{TSP and its chemical components}

TSP concentrations are generally found to be high in the Indian region as compared to those in North America and Western Europe. Especially in the north western India, values ranging from 100 to $500 \mu \mathrm{g} / \mathrm{m}^{3}$ have been reported which was attributed to the dust from adjoining arid regions (Khemani, 1993). Rao et al, 2001 have reported $108 \mu \mathrm{g} / \mathrm{m}^{3}$ average concentration of TSP at Pune in the winter season of 1998. In the present study, concentrations of TSP were more at Pune than those at Sinhagad during the winter season of 2003/4 (Figure 2). This could be obviously due to the more human activities at Pashan, Pune, being a semi-urban location. Also, the concentrations of TSP go on decreasing as the altitude of the location increases (Junge, 1963). Mahadevan et al (1989) have reported average TSP concentration of $22 \mu \mathrm{g} / \mathrm{m}^{3}$ at Mallikadevi, a site in the foothills of Himalayas at an altitude of about $2200 \mathrm{~m}$ asl. All the chemical constituents of TSP were more at Pune (except sea salt i e., $\mathrm{Na}^{+}$and $\mathrm{Cl}^{-}$). Especially, concentrations of $\mathrm{NO}_{3}{ }^{-}$and $\mathrm{Ca}^{2+}$ showed much high values at Pune, mainly due to high density of vehicular population and also due to the rapid construction activity going on, in and around the city. Whereas, at Sinhagad, these activities are comparatively less and also the extent of vegetation cover is more in the surrounding areas which leaves less open land that generally acts as a source for $\mathrm{Ca}^{2+}$ aerosols. As seen from Figure 3, concentrations of TSP and its 
chemical constituents especially, $\mathrm{NO}_{3}{ }^{-}, \mathrm{NH}_{4}{ }^{+}$and $\mathrm{Ca}^{2+}$ were more at Sinhagad on holidays (Saturdays and Sundays) than those on non-holidays (Monday to Friday). Concentration of $\mathrm{F}^{-}$was about 0.04 $\mu \mathrm{g} / \mathrm{m}^{3}$ on holidays whereas on non-holidays, it was below the detection limits. Baum et al (1972) have reported burning of coal as one of the sources for $\mathrm{F}^{-}$. This feature indicates towards the impact of increased fuel/biomass burning activities at the hill station, generally observed on holidays.

Khemani (1989) has earlier reported studies on TSP and its composition at these two locations and the present results have been compared with those reported by him (Figure 4). Similar feature with more concentration of TSP and its chemical components was observed. However, at both the locations, there is a significant increase in TSP and constituent ionic components. The average concentration of TSP at Pune $\left(170.8 \mu \mathrm{g} / \mathrm{m}^{3}\right)$ increased by about 1.7 times in 2004 as compared to that in $1978\left(100 \mu \mathrm{g} / \mathrm{m}^{3}\right)$. Whereas, at Sinhagad the average concentration of TSP $\left(112 \mu \mathrm{g} / \mathrm{m}^{3}\right)$ increased by about 2.5 times in 2004 as compared to that $\left(45 \mu \mathrm{g} / \mathrm{m}^{3}\right)$ in 1982 . There was about 7 times rise in the concentrations of both $\mathrm{SO}_{4}{ }^{2-}$ and $\mathrm{NO}_{3}{ }^{-}$at Pune whereas at Sinhagad, concentrations of both these constituents increased by about 10 times, after the period of two decades. Also, concentrations of $\mathrm{Ca}^{2+}$ increased by about 4 times at Pune and that at Sinhagad by about 6 times. But the most significant increase was in the concentration of $\mathrm{NH}_{4}{ }^{+}$, which was more than 23 times at Sinhagad and about 9 times at Pune. Concentration of $\mathrm{F}^{-}$was found to be very low (average value was $0.01 \mu \mathrm{g} / \mathrm{m}^{3}$ ) at Sinhagad during 2003/4 whereas at Pune, the average concentration was about $0.1 \mu \mathrm{g} / \mathrm{m}^{3}$. Concentration of $\mathrm{F}^{-}$was not carried out in the earlier study (Khemani, 1989) due to non-availability of Ion Chromatograph. Fluoride aerosols are generally originated from various anthropogenic sources like solid waste disposal, emissions from aluminium and steel industries, use of phosphate fertilizers, etc.( Rose and Marier, 1977). The one order more concentration of $\mathrm{F}^{-}$at Pune indicates the effect of urbanization and emissions from surrounding industrial areas.

Numerous settlements have come up on the Sinhagad Fort during the past few years as the tourist activities have increased. Consequently, there is an increase in the burning of biomass, as the cheapest and most affordable means for cooking. In addition to it, due to the increasing tourist activities, vehicular emissions of precursor gases for sulfur and nitrogen species have added subsequently to the production of sulfurous and nitrogenous aerosols (Crutzen and Andreae, 1990). Apart from fertilizer use, animal and human excretions are reported to be the major sources for $\mathrm{NH}_{4}{ }^{+}$in aerosols (Galbally and Gillett, 1988). Increase in human population and activities related to animal husbandry were one of the main reasons for the increase in $\mathrm{NH}_{4}{ }^{+}$at Sinhagad and Pune. Vegetative emissions could be an important source for $\mathrm{K}^{+}$aerosols at Sinhagad. Similar results have been earlier reported at Silent Valley forest in south India (Safai et al, 1993). In the Indian region, crustal source has been widely referred for $\mathrm{Ca}^{2+}, \mathrm{Mg}^{2+}$ and $\mathrm{K}^{+}$and marine source for $\mathrm{Na}^{+}$and $\mathrm{Cl}^{-}$(Khemani, 1989). Sea salt fractions were calculated to assess the marine contribution towards chemical composition of TSP, using the standard sea water ratios for different components with reference to $\mathrm{Na}^{+}$(Keene et al, 1986). Sea salt contribution was computed for $\mathrm{Ca}^{2+}, \mathrm{K}^{+}, \mathrm{Mg}^{2+}$ and $\mathrm{SO}_{4}{ }^{2-}$, because $\mathrm{Cl}{ }^{-}$is mainly from sea and the marine contribution for nitrogenous components like $\mathrm{NO}_{3}{ }^{-}$and $\mathrm{NH}_{4}{ }^{+}$is very meager (as seen from the 
bulk sea water composition reported by Horn and Adams,1966). Table 2 shows the non-seasalt (Nss) contribution for $\mathrm{SO}_{4}{ }^{2-}, \mathrm{Ca}^{2+}, \mathrm{K}^{+}$and $\mathrm{Mg}^{2+}$. A decrease in marine contribution for all of these components was observed after the period of two decades, at both Pune and Sinhagad.

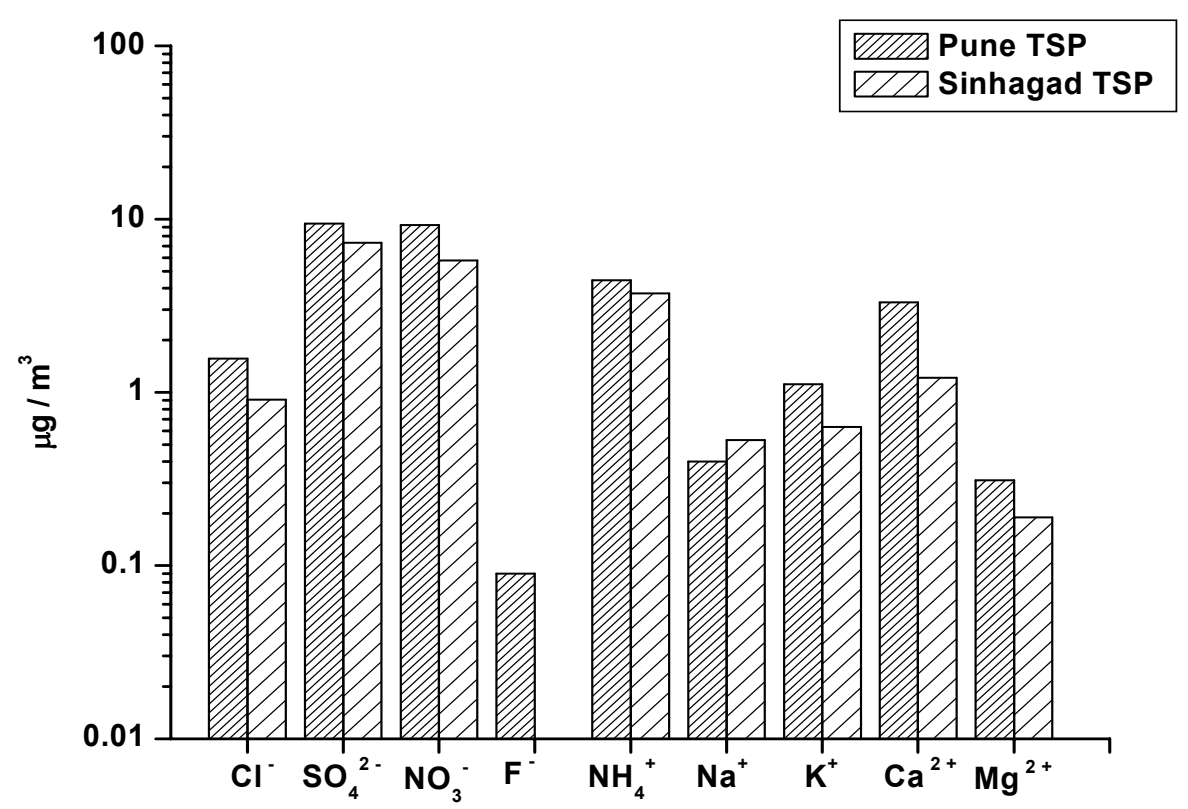

Figure 2. Ionic composition of TSP at Pune and Sinhagad in the winter season of 2004.

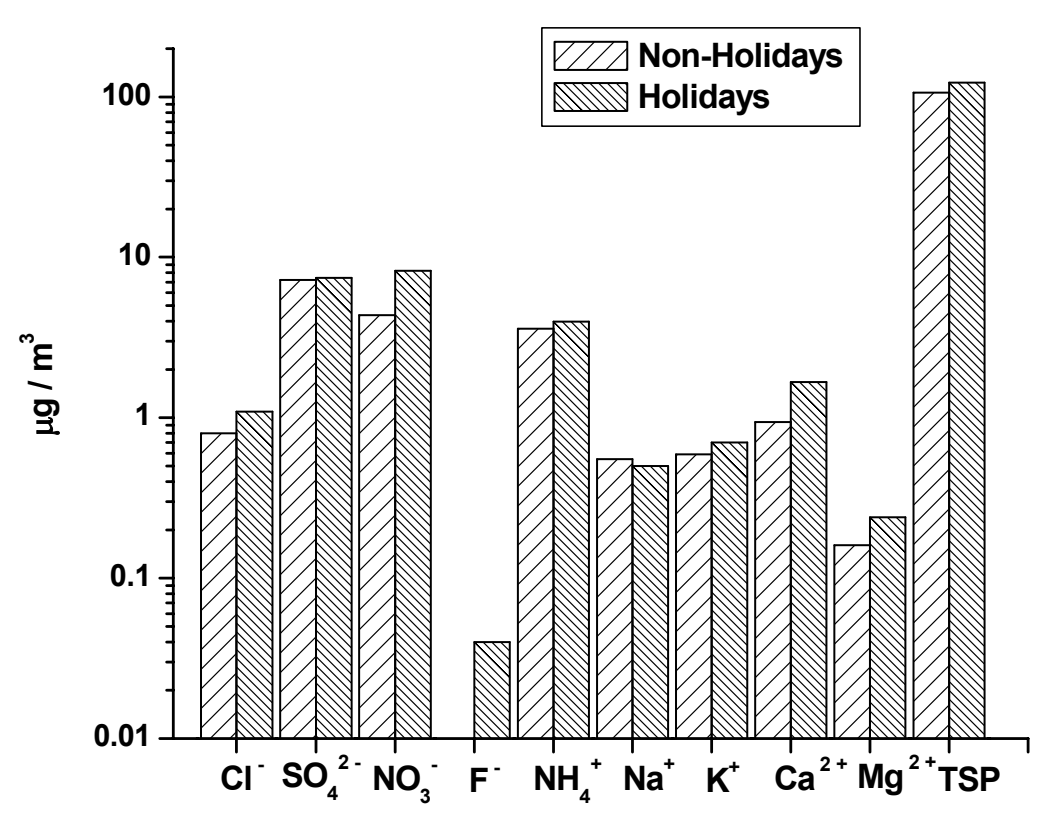

Figure 3. Ionic composition of TSP at Sinhagad on holidays and non-holidays. 


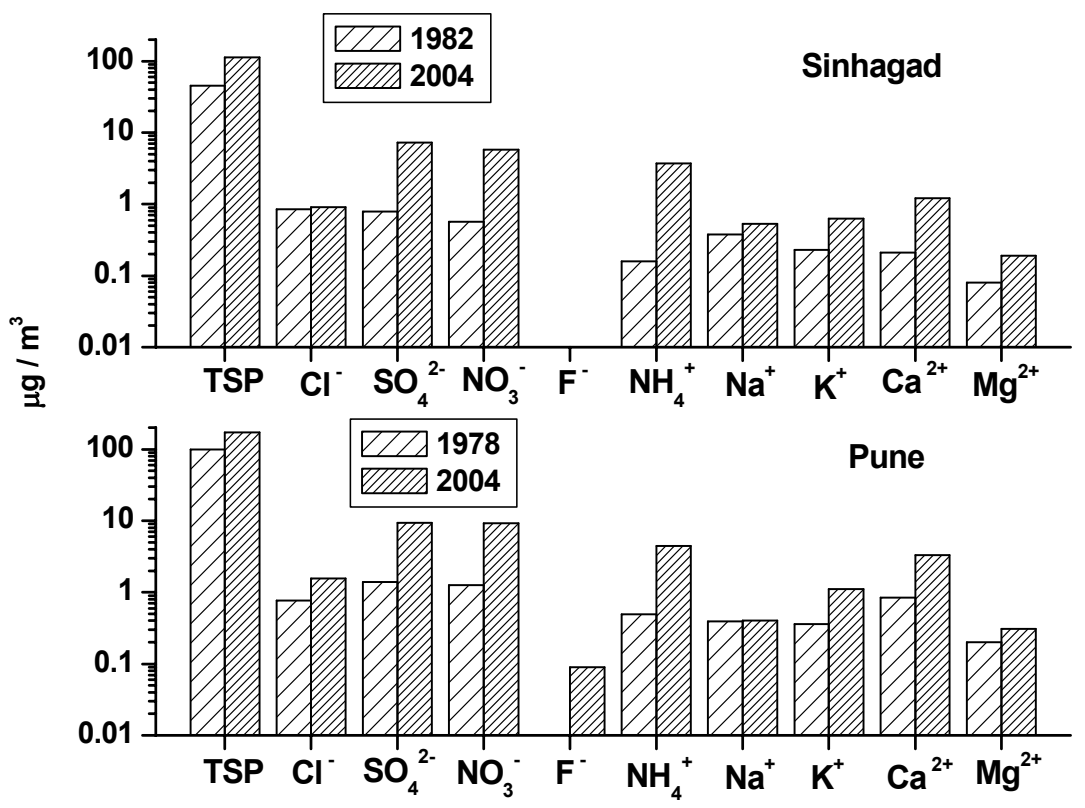

Figure 4. Variation in the concentrations of TSP and its ionic constituents at Pune and Sinhagad after a period of two decades.

Table 1. Percentage contributions of ionic constituents to the total composition of TSP during the winter season at Pune and Sinhagad.

\begin{tabular}{|c|c|c|c|c|}
\hline \multirow[t]{2}{*}{$\begin{array}{c}\text { Ionic } \\
\text { Constituent }\end{array}$} & \multicolumn{2}{|c|}{$\begin{array}{c}\text { Pune } \\
\% \text { Contribution to TSP }\end{array}$} & \multicolumn{2}{|c|}{$\begin{array}{c}\text { Sinhagad } \\
\text { \% Contribution to TSP }\end{array}$} \\
\hline & 1978 & 2004 & 1982 & 2004 \\
\hline $\mathrm{Cl}^{-}$ & 12 & 5 & 24 & 4 \\
\hline $\mathrm{SO}_{4}{ }^{2-}$ & 16 & 23 & 17 & 26 \\
\hline $\mathrm{NO}_{3}^{-}$ & 11 & 17 & 9 & 16 \\
\hline $\mathrm{NH}_{4}^{+}$ & 15 & 28 & 9 & 35 \\
\hline $\mathrm{Na}^{+}$ & 9 & 2 & 17 & 4 \\
\hline $\mathrm{K}^{+}$ & 5 & 3 & 6 & 3 \\
\hline $\mathrm{Ca}^{2+}$ & 23 & 19 & 11 & 10.5 \\
\hline $\mathrm{Mg}^{2+}$ & 9 & 3 & 7 & 2.5 \\
\hline
\end{tabular}


Table 2. Marine contribution towards $\mathrm{SO}_{4}{ }^{2-}, \mathrm{Ca}^{2+}, \mathrm{K}^{+}$and $\mathrm{Mg}^{2+}$ in TSP at Pune and Sinhagad.

\begin{tabular}{|c|c|c|c|c|c|}
\hline \multirow{2}{*}{ Location } & \multirow{2}{*}{ Year } & \multicolumn{4}{|c|}{ Percentage contribution of marine source } \\
\cline { 3 - 6 } & & $\mathrm{SO}_{4}{ }^{2-}$ & $\mathrm{Ca}^{2+}$ & $\mathrm{K}^{+}$ & $\mathrm{Mg}^{2+}$ \\
\hline \multirow{2}{*}{ Pune } & 1978 & 7.0 & 2.0 & 4.0 & 23.0 \\
\cline { 2 - 6 } & 2004 & 1.0 & 0.5 & 1.0 & 15.0 \\
\hline \multirow{2}{*}{ Sinhagad } & 1982 & 13.0 & 7.0 & 6.0 & 56.0 \\
\cline { 2 - 6 } & 2004 & 2.0 & 1.0 & 3.0 & 33.0 \\
\hline
\end{tabular}

Table 1 shows the percentage contributions of different ionic components to the total composition of TSP during the winter season of 2003/4 at Pune and Sinhagad along with those observed for the same locations, from the data reported by Khemani (1989). It can be seen that the contributions of $\mathrm{SO}_{4}{ }^{2-}, \mathrm{NO}_{3}{ }^{-}$and $\mathrm{NH}_{4}{ }^{+}$have increased at both the locations. The increase in the contribution of $\mathrm{NH}_{4}{ }^{+}$is highly significant (two times more at Pune and about four times more at Sinhagad). However, there is a reduction in the percentage contribution of all the other ionic components. Thus, the impact of anthropogenically produced (mainly biomass and fuel burning) aerosols has been increasing than those by natural sources like soil $\left(\mathrm{Ca}^{2+}, \mathrm{K}^{+}, \mathrm{Mg}^{2+}\right)$ and sea $\left(\mathrm{Na}^{+}\right.$and $\left.\mathrm{Cl}^{-}\right)$at Pune and Sinhagad.

\subsection{Acidic components of TSP}

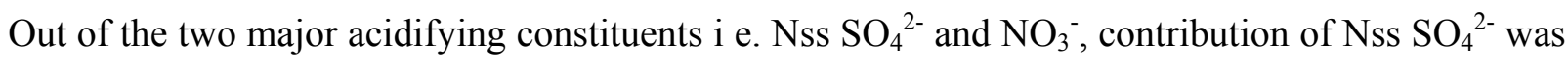
found to be more towards acidification of aerosols at Pune as well as at Sinhagad. This could be seen from the ratio, $\left[\mathrm{NO}_{3}{ }^{-}\right] /\left[\mathrm{Nss}_{\mathrm{SO}_{4}}{ }^{2-}\right]+\left[\mathrm{NO}_{3}{ }^{-}\right]$which shows the relative contribution of $\mathrm{NO}_{3}{ }^{-}$to the total

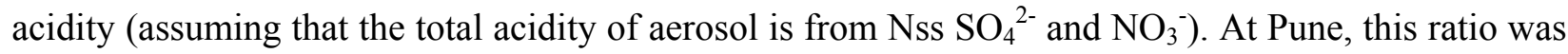

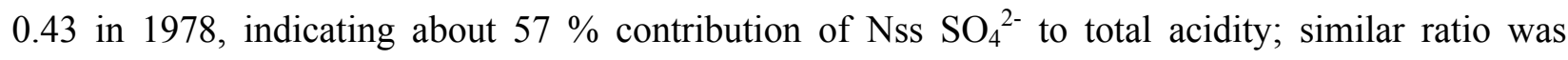
observed in 2004, indicating the same contribution. At Sinhagad, this ratio was 0.39 in 1982 and 0.38 in 2004 , indicating $\geq 60 \%$ contribution from ${\mathrm{Nss} \mathrm{SO}_{4}}^{2-}$ to the total acidity of aerosols. Thus, the overall contribution of $\mathrm{Nss} \mathrm{SO}_{4}{ }^{2-}$ to the acidity was earlier about $60 \%$ and has still remained almost unchanged. Rao et al (2004) have reported results of aerosol studies at Sinhagad for 2002-03, using a Filter Pack method. Acidic fine aerosols and alkaline coarse aerosols were observed and this feature was attributed to the dominance of $\mathrm{SO}_{4}{ }^{2-}$ in fine and that of $\mathrm{Ca}^{2+}$ in coarse size particles. Also, they have reported high concentrations of $\mathrm{SO}_{4}{ }^{2-}$ and $\mathrm{NH}_{4}{ }^{+}$in aerosols during winter. 


\subsection{Neutralization potential of TSP}

Considering $\mathrm{SO}_{4}{ }^{2-}$ and $\mathrm{NO}_{3}{ }^{-}$as the main acidifying components and $\mathrm{Ca}^{2+}$ and $\mathrm{NH}_{4}{ }^{+}$as main neutralizing components, the ratio NP/AP i e. ratio of Neutralization Potential to Acidic Potential was computed as follows,

$$
\mathrm{NP} / \mathrm{AP}=\left(\left[\mathrm{Nss} \mathrm{Ca}^{2+}\right]+\left[\mathrm{NH}_{4}^{+}\right]\right) /\left(\left[\mathrm{Nss} \mathrm{SO}_{4}{ }^{2-}\right]+\left[\mathrm{NO}_{3}{ }^{-}\right]\right)
$$

The NP/AP value was 1.45 in 1978 at Pune, which decreased up to 1.20 in 2003/4, indicating reduction in the neutralization potential of aerosols. Similar feature has been observed for rain water at Pune at the same location, during the course of two decades, i.e. 1984 to 2002 (Safai et al, 2004b). At Sinhagad, this ratio was about 0.79 in 1982 and 1.10 in 2004, indicating increase in the neutralization potential of aerosols, in spite of increase in the concentrations of $\mathrm{SO}_{4}{ }^{2-}$ and $\mathrm{NO}_{3}{ }^{-}$. $\mathrm{This}^{-}$ phenomenon is mainly due to the substantial rise in the concentrations of $\mathrm{NH}_{4}^{+}$aerosols. The neutralization factors for all the major cations were computed (Parashar et al, 1996). As seen from Figure. 5, $\mathrm{Ca}^{2+}$ was the main neutralizing constituent of aerosols at both Pune and Sinhagad. It contributed about $52 \%$ to the total neutralisation potential in 1982 at Sinhagad and about $60 \%$ in 1978 at Pune. However, in 2003/4, $\mathrm{NH}_{4}{ }^{+}$contributed more towards neutralization of acidity at Sinhagad $(\sim 79 \%)$ and at Pune ( about $60 \%)$.

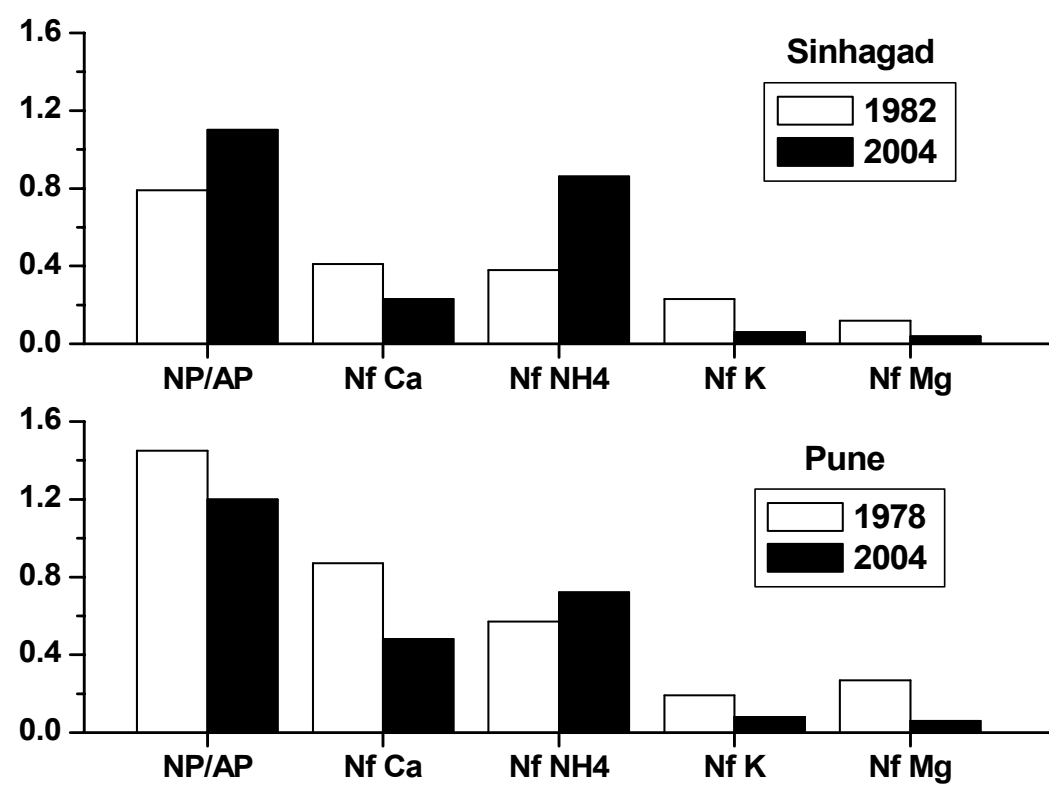

Figure 5. Neutralisation Potential / Acidic Potential of TSP and Neutralisation Factors for different cations of TSP at Pune and Sinhagad 


\section{Conclusions}

Concentrations of TSP and its chemical constituents, mainly $\mathrm{SO}_{4}{ }^{2-}, \mathrm{NO}_{3}{ }^{-}, \mathrm{NH}_{4}{ }^{+}$and $\mathrm{Ca}^{2+}$ have increased significantly at Pune as well as at Sinhagad after a period of about two decades (1980's to 2003/4) indicating the increasing impact of anthropogenic activities. $\mathrm{SO}_{4}{ }^{2-}$ was the major contributor for acidity whereas, $\mathrm{NH}_{4}{ }^{+}$showed more neutralization potential than $\mathrm{Ca}^{2+}$ (which was earlier the dominant neutralizing cation).

\section{Acknowledgements}

Authors are thankful to the Director, Indian Institute of Tropical Meteorology, Pune for the encouragement to undertake these studies. Thanks are also due to the authorities of Bharat Sanchar Nigam Limited (BSNL), Pune, for allowing us to carry out the observations and giving all possible help at the microwave station at Sinhagad. Finally, we are indebted to the ISRO-GBP Programme of ISRO, Department of Space, Government of India for the financial support for carrying out these studies.

\section{References}

Ali K., Chate D.M., Tiwari S., Rao P.S.P., Momin G.A., Safai P.D., Praveen P.S. and Naik M.S. (2002), Some aspects of aerosols at industrial and residential locations of Delhi. In: IASTA Bulletin, 14/1, Proc. Conf. on Aerosol remote sensing in global change and atmospheric pollution, Thiruvananthapuram, India, pp. 152-154.

Baum von F., Giebel J. and Brell H. (1972), Uber die Erfassung gasformiger Schadstoffe bei steinkohlegefeuerten Einzelofen. Gesundh. Ing. 93: 102-108.

Crutzen P.J. and Andreae M.O. (1990), Biomass burning in the tropics: Impact on Atmospheric chemistry and biogeochemical cycles, Science. 250: 1669-1678. Devara P.C.S., Maheskumar R.S., Raj P.E., Pandithurai G. and Dani K.K. (2001), Recent trends in aerosol climatology and air pollution as inferred from multi-year lidar observations over a tropical urban station. Intl. J. Climatol. 22: 435-449.

Devara P.C.S., Maheskumar R.S., Raj P.E., Pandithurai G. and Dani K.K. (2001), Recent trends in aerosol climatology and air pollution as inferred from multi-year lidar observations over a tropical urban station. Intl. J. Climatol.22: 435-449.

District Social and Economic Summary, Pune District (1999-2000), Directorate of Economics and Statistics, Government of Maharashtra, Mumbai, India

Galbally I.E. and Gillett R.W. (1988), Processes regulating nitrogen compound in the tropical atmosphere. In Acidification in Tropical Countries, Ed. by Rodhe H. and Herrera R., SCOPE 36, Publ. by John Wiley and Sons Ltd., 73-116. 
Horn M.K. and Adams J.A.S. (1966), Computer-derived geochemical balances and element abundances. Geochimica et Cosmochimica Acta. 30: 279-297.

Junge C.E. (1963), Air chemistry and Radioactivity, Academic Press, N. Y.

Keene W.C., Pszenny A. P., Galloway J.N. and Hawley M.E.(1986), Sea salt corrections and interpretations of constituent ratios in marine precipitation. J. Geophys. Res. 91: 6647-6658.

Khemani L T., Momin G.A., Naik M.S., Vijayakumar R. and Ramana Murty Bh. V. (1982), Chemical composition and size distribution of atmospheric aerosols over the Deccan Plateau, India. Tellus. 34: 151-155.

Khemani LT., Momin G.A., Naik M.S., Rao P.S.P., Kumar R. and Ramana Murty Bh. V. (1985), Trace elements and sea salt aerosols over the sea areas around the Indian sub-continent. Atmos. Environ. 19: 277-284.

Khemani L.T. (1989), Physical and chemical characteristics of atmospheric aerosols. In Air Pollution Control, Vol. 2, Encyclopedia of Environmental Control Technology, Gulf Publ. Co., USA, p. $401-452$.

Khemani L.T. (1993), Air pollution and acid rain problems in the Indian region. Indian J. Radio and Space Phys. 22: 207-214.

Kulshrestha U.C., Saxena A., Kumar N., Kumari K.M. and Srivastava S.S.(1998), Chemical composition and association of size-differentiated aerosols at a suburban site in a semi-arid tract of India. J. Atmos. Chem. 29: 109-118.

Mahadevan T N, Negi B S. and Meenakshy V. (1989), Measurements of elemental composition of aerosol matter and precipitation from a remote background site in India. Atmos. Environ. 23: 869874.

Momin G.A., Rao P.S.P., Safai P.D., Ali K., Naik M.S. and Pillai A.G. (1999), Atmospheric aerosol characteristic studies at Pune and Thiruvananthapuram during INDOEX programme-1998. Current Sci. 76: 985-989.

Parashar D.C., Granat L., Kulshrestha U.C., Pillai A.G., Naik M.S., Momin G.A., Prakasa Rao P. S., Safai P.D., Khemani L.T., Naqvi S.W.A., Narvekar P.V., Thapa K.B. and Rodhe, H. (1996), Chemical composition of precipitation in India and Nepal. A preliminary report on an IndoSwedish project on atmospheric chemistry: Department of Meteorology, Stockholm University, International Meteorological Institute, Stockholm, CM-90.

Rao P.S.P., Momin G.A., Safai P.D., Ali K., Naik M.S. and Pillai A.G. (2001), Aerosol and trace gas studies at Pune during INDOEX IFP-99. Current Sci. 80: 105-109.

Rao P.S.P., Praveen P.S., Safai P.D., Momin G.A., Ali K., Chate D.M.,Granat L. and Rodhe R. (2004), Chemical characteristics of fine and coarse aerosols at Sinhagad-A high altitude location. In: IASTA Bulletin, 16/1\&2, Proc. Int. Conf. on Aerosol, Clouds and Indian Monsoon, Kanpur, India, pp.389-392.

Rose D. and Marier J.R. (1977), Environmental Fluoride 1977, NRC Associate Committee on Scientific Criteria for Environmental Quality, National Research Council of Canada, NRCC NO. 
16081, ISSN 0114-0116.

Safai P.D., Khemani L.T., Momin G.A., Rao P.S.P. and Pillai A.G. (1993), Mass size distribution and chemical composition of aerosols at the Silent Valley. India. Indian J. Radio and Space Phys. 22: 56-61.

Safai P.D. (1999), A study of the air pollutants in the environment of the Nilgiri Biosphere Reserve, South India, Ph. D. thesis, University of Pune, Pune,

Safai P.D., Rao P.S.P., Momin G.A., Ali K., Tiwari S., Naik M.S. and Kuniyal J.C. (2004a), Chemical composition of size - separated aerosols at two rural locations in the Himalayan region. Ind. J. Radio and Space Phys. 30: 270-277.

Safai P.D., Rao P.S.P., Momin G.A., Ali K., Chate D.M. and Praveen P.S. (2004b), Chemical Composition of Precipitation during 1984 - 2002 at Pune, India. Atmos. Environ. 38: 1705-1714.

Weatherburn A. (1967), Phenol-hypochlorite reaction for determination of ammonia. Anal. Chem. 39: 971-974.

Received for review, March 10, 2005

Accepted, May 11,2005 